\title{
Métodos de micropropagação de abacaxizeiro
}

\author{
Adriano Bortolotti da Silva( ${ }^{(1)}$, Moacir Pasqual(2), João Batista Teixeira ${ }^{(3)}$ e Aparecida Gomes de Araújo(2)
}

\begin{abstract}
(1)Universidade José do Rosário Vellano, Instituto de Ciências Agrárias, Rod. MG 179, Km 0, CEP 37130-000 Alfenas, MG. E-mail: bortolot@bol.com.br (2)Universidade Federal de Lavras, Caixa Postal 37, CEP 37200-000 Lavras, MG. E-mail: mpasqual@ufla.br, agaraujo2003@hotmail.com ${ }^{(3)}$ Embrapa Recursos Genéticos e Biotecnologia, Caixa Postal 02372, CEP $70770-900$ Brasília, DF. E-mail: batista@cenargen.embrapa.br
\end{abstract}

\begin{abstract}
Resumo - O objetivo deste trabalho foi comparar diferentes métodos de micropropagação in vitro de abacaxizeiro em larga escala. Os tratamentos utilizados foram micropropagação convencional em meio sólido $\left(5\right.$ e $6 \mathrm{~g} \mathrm{~L}^{-1}$ de ágar) e em meio líquido, e micropropagação em biorreator de imersão temporária - imersão no meio de cultura a cada 2, 4 e 8 horas, por 3 min - e contínua, com aeração a cada 2, 4 e 8 horas, por 3 min. Utilizou-se meio MS suplementado com $1 \mathrm{mg} \mathrm{L}^{-1}$ de BAP, $0,25 \mathrm{mg} \mathrm{L}^{-1}$ de ANA, $\mathrm{pH}$ ajustado para 5,8. As culturas foram mantidas em sala de crescimento $\operatorname{com} 25 \pm 1^{\circ} \mathrm{C}$, sob luz branca fria $\left(40 \mu \mathrm{mol} \mathrm{m}^{-2} \mathrm{~s}^{-1}\right)$, com 16 horas de fotoperíodo. O delineamento foi inteiramente casualizado, com nove tratamentos e quatro repetições. Depois de 45 dias de cultivo, foram avaliados número de brotos, brotações superiores a $1 \mathrm{~cm}$, comprimento de brotos, massa de matéria fresca e massa de matéria seca de brotos. Sistemas de imersão temporária, com as plântulas imersas a cada 2 horas por 3 min, proporcionaram maior número, altura e massa de matéria seca de brotos de abacaxizeiro. $\mathrm{O}$ sistema de imersão temporária é o método mais eficiente na micropropagação de abacaxizeiro em larga escala.
\end{abstract}

Termos para indexação: Ananas comosus, propagação vegetal, imersão temporária.

\section{Micropropagation methods of pineapple}

\begin{abstract}
The objective of this work was to compare different methods of pineapple in vitro mass micropropagation. The treatments were conventional micropropagation in solid medium ( 5 and $6 \mathrm{~g} \mathrm{~L}^{-1}$ agar) and in liquid medium, micropropagation in bioreactor of temporary immersion (immersion in culture medium each 2 , 4 and 8 hours, for 3 minutes) and continuous immersion (with aeration each 2, 4 and 8 hours, for 3 minutes). MS medium supplement with $1 \mathrm{mg} \mathrm{L}^{-1} \mathrm{BAP}, 0.25 \mathrm{mg} \mathrm{L}^{-1} \mathrm{NAA}$, and $\mathrm{pH}$ adjusted to 5.8 was utilized. Cultures were incubated at $25 \pm 1^{\circ} \mathrm{C}$ under cool white fluorescent tubes $\left(40 \mu \mathrm{mol} \mathrm{m}^{-2} \mathrm{~s}^{-1}\right)$ with a 16-hours photoperiod. The experiment design was completely randomized, comprising nine treatments and four replicates. After 45 days, number of shootings, shootings higher than $1 \mathrm{~cm}$, length of shootings, fresh matter of shootings and dry matter of shootings were evaluated. Temporary immersion system in each 2 hours for 3 minutes provided higher number, height and dry matter of pineapple shootings. Temporary immersion system is the most efficient method in pineapple mass micropropagation.
\end{abstract}

Index terms: Ananas comosus, vegetal propagation, temporary immersion.

\section{Introdução}

A produção de mudas de abacaxizeiro em larga escala livres de patógenos tem sido um dos principais fatores limitantes ao desenvolvimento eficiente da cultura. Os métodos utilizados na propagação convencional de abacaxizeiro apresentam baixo rendimento de mudas e podem disseminar a fusariose (Fusarium subglutinans f. sp. ananas), doença responsável por perdas de produtividade no campo. As técnicas de cultura de tecidos têm apresentado vantagens em relação ao método convencional, como, por exemplo, a produção de mudas livres de fitopatógenos (Reinhardt \& Cunha, 1999).
A micropropagação comercial de abacaxizeiro envolve o cultivo seqüencial em meio líquido de explantes (micropropagação convencional) advindos de cultura de meristemas e gemas axilares (Danquita \& Benega, 1997). Entretanto, o emprego comercial desta técnica é reduzido em virtude dos altos custos de produção, principalmente com mão-de-obra e perdas durante o processo de aclimatização (Kitto, 1997).

O cultivo de explantes em meio líquido possibilita a automação do processo de micropropagação e, conseqüentemente, a redução dos custos relativos à mão-de-obra. Várias pesquisas utilizando sistemas de 
automação, principalmente o uso de biorreatores, para a micropropagação em meio líquido, têm sido relatadas (Escalona et al., 1999; Ziv, 1999; Paek et al., 2001). O emprego de biorreatores em cultivo líquido permite a micropropagação em larga escala, a prevenção de distúrbios fisiológicos dos brotos e a hiperidricidade. Ainda existe a possibilidade de computadores serem usados no controle de sistemas de biorreatores, apresentando, dessa forma, vantagens sobre a micropropagação convencional em termos de automação e redução de trabalho.

Os sistemas de cultivo em biorreatores podem ser divididos em contínuos ou temporários. No sistema contínuo, os explantes ficam sempre em contato com o meio de cultura, enquanto no sistema temporário, o material vegetal entra em contato com o meio de cultura de tempos em tempos, de acordo com programação predefinida (Alvard et al., 1993; George, 1996). Segundo Lemos (2001), a imersão temporária em bananeira apresentou maior eficiência na produção de biomassa, maior número de brotos viáveis à aclimatização e maior crescimento dos explantes quando comparado com o sistema tradicional.

A propagação em larga escala por meio de biorreatores tem sido relatada com sucesso em várias espécies, como bananeira (Alvard et al., 1993), cana-de-açúcar (Lorenzo et al., 1998), orquídea (Paek et al., 2001) e abacaxizeiro (Escalona et al., 1999), apresentando taxa de multiplicação superior quando comparada com a micropropagação convencional.

O objetivo deste trabalho foi comparar diferentes métodos de micropropagação in vitro de abacaxizeiro em larga escala.

\section{Material e Métodos}

O experimento foi conduzido no Laboratório de Cultura de Tecidos Vegetais, do Departamento de Agricultura da Universidade Federal de Lavras, Lavras, MG, durante o ano de 2005.

Os explantes de abacaxizeiro (Ananas comosus (L.) Merr. cultivar Imperial) utilizados no experimento foram obtidos a partir do estabelecimento in vitro de gemas axilares em meio líquido MS (Murashige \& Skoog, 1962) suplementado com $1 \mathrm{mg} \mathrm{L}^{-1}$ de BAP, $0,25 \mathrm{mg} \mathrm{L}^{-1}$ de ANA, $30 \mathrm{~g} \mathrm{~L}^{-1}$ de sacarose e $\mathrm{pH}$ ajustado para 5,8 . Os cultivos foram mantidos em sala de crescimento, por 60 dias, com irradiância de $40 \mu \mathrm{mol} \mathrm{m}^{-2} \mathrm{~s}^{-1}$ fornecida por luz branca fria, com 16 horas de fotoperíodo a $25 \pm 1^{\circ} \mathrm{C}$.

Na comparação dos diferentes métodos de cultivo, os tratamentos utilizados foram micropropagação convencional em meio sólido (5 e $6 \mathrm{~g} \mathrm{~L}^{-1}$ de ágar) e em meio líquido, e micropropagação em biorreator de imersão temporária (imersão a cada 2, 4 e 8 horas), e contínua (com aeração a cada 2, 4 e 8 horas), num total de nove tratamentos, com quatro repetições.

Na micropropagação convencional, em meio sólido e líquido foram colocados três explantes, em frascos de $250 \mathrm{~mL}$, com $30 \mathrm{~mL}$ de meio de cultura. No cultivo em meio sólido, utilizaram-se duas concentrações de ágar ( 5 e $6 \mathrm{~g} \mathrm{~L}^{-1}$ ). $\mathrm{O} \mathrm{pH}$ do meio de cultura foi ajustado para 5,8 antes da autoclavagem a $121^{\circ} \mathrm{C}$ e $1 \mathrm{~kg} \mathrm{~cm}^{-1}$, por $20 \mathrm{~min}$.

No cultivo em biorreator, foram colocados dez explantes em $300 \mathrm{~mL}$ de meio de cultura, em frascos de 1 L. No sistema de imersão temporária, os explantes foram imersos no meio de cultura a cada 2, 4 e 8 horas, por 3 min. No sistema de imersão contínua, a aeração foi realizada em diferentes tempos: a cada 2, 4 e 8 horas, por 3 min.

Foi utilizado meio MS suplementado com $1 \mathrm{mg} \mathrm{L}^{-1} \mathrm{de}$ BAP, 0,25 $\mathrm{mg} \mathrm{L}^{-1}$ de ANA, pH ajustado para 5,8. As culturas foram mantidas em sala de crescimento com $25 \pm 1^{\circ} \mathrm{C}$, sob luz branca fria $\left(40 \mu \mathrm{mol} \mathrm{m} \mathrm{m}^{-2} \mathrm{~s}^{-1}\right)$, com 16 horas de fotoperíodo.

O sistema de biorreator de imersão temporária é constituído por dois frascos conectados por tubos de silicone; um dos frascos contém o meio de cultura e no outro ocorre o cultivo dos explantes, modelo similar ao sistema de frascos gêmeos-BIT, utilizado por Escalona et al. (1999), que foi desenvolvido por Teixeira (2002). Nesse sistema, o ar fornecido por um compressor é esterilizado por uma membrana de $0,22 \mu \mathrm{m}$, entra no frasco que contém o meio de cultura e faz com que o líquido chegue ao outro frasco que contém os explantes. Após um tempo de imersão, ocorre reversão do processo: o meio nutritivo retorna para seu frasco. A freqüência e o tempo de imersão são controlados por "timers" eletrônicos e válvulas solenóides (Escalona et al., 1999). O tempo de imersão pode variar e o ar promove a renovação da atmosfera do frasco.

No sistema de biorreator de imersão contínua, foi realizada adaptação no sistema desenvolvido por Teixeira (2002): os tubos de silicone que unem os dois frascos gêmeos foram desconectados. Cada um dos recipientes apresenta dois orifícios e, assim, um foi usado para entrada de ar, esterilizado por uma membrana de $0,22 \mu \mathrm{m}$ e o outro foi usado para saída de excesso de pressão. A entrada de ar no frasco promove a renovação da atmosfera.

Após 45 dias de cultivo, os seguintes parâmetros foram avaliados: número de brotos, brotações superiores 
a $1 \mathrm{~cm}$, comprimento de brotos, massa de matéria fresca e massa de matéria seca de brotos. A massa de matéria seca foi medida após a secagem em estufa por cinco dias a $50^{\circ} \mathrm{C}$.

$\mathrm{O}$ experimento foi conduzido em delineamento inteiramente casualizado, com nove tratamentos e quatro repetições. Os dados foram submetidos à análise de variância e as médias comparadas pelo teste de Scott \& Knott, a 5\% de probabilidade. As análises estatísticas foram realizadas utilizando-se o SISVAR 4.3 (Ferreira, 1999).

\section{Resultados e Discussão}

O número de brotos foi afetado pelos métodos de cultivo. A imersão temporária a cada 2, 4 e 8 horas e a imersão contínua a cada duas horas apresentaram os melhores resultados com cerca de 19 brotações por explante, enquanto o cultivo em meio sólido com $6 \mathrm{~g} \mathrm{~L}^{-1}$ apresentou o pior desempenho (Tabela 1). Os sistemas de cultivo em biorreator podem promover brotações em larga escala, o que possibilita a automação do processo de micropropagação e a redução do trabalho (Paek et al., 2001). Lorenzo et al. (1998) observaram em sistema de imersão temporária taxa de multiplicação de 23,9 brotos em 30 dias, seis vezes superior ao protocolo convencional para cana-de-açúcar. Escalona et al. (1999) observaram que a imersão temporária estimulou a multiplicação e a massa de matéria seca dos brotos de abacaxizeiro. Mais de 5.000 brotações foram obtidas em um único frasco, taxa de multiplicação de 300 a $400 \%$ em relação ao convencional.

Neste trabalho, o sistema de automação proporcionou taxas de multiplicação de 136 até $316 \%$ superiores, quando comparadas aos sistemas de micropropagação convencional. Entretanto, o uso da imersão contínua, que proporcionou número razoável de brotos, pode dobrar a capacidade do biorreator - por usar somente um frasco de cultivo - quando comparado aos sistemas de imersão temporária, no qual utilizam-se dois frascos para o cultivo.

Os sistemas de imersão temporária, com programação a cada 2 e 4 horas, apresentaram os melhores resultados quanto às variáveis número de brotos maiores que $1 \mathrm{~cm}$ e comprimento de brotos, com 17 brotos e $2,5 \mathrm{~cm}$, respectivamente (Tabela 1). A produção de brotos maiores pode proporcionar maior sobrevivência das mudas durante o processo de aclimatização de abacaxizeiro (Escalona et al., 1999).

Os métodos de micropropagação convencional apresentaram baixo crescimento de brotos (Tabela 1), provavelmente devido à pouca possibilidade de trocas gasosas nestes sistemas (Etienne \& Berthouly, 2002).

Os explantes cultivados em meio líquido em condições de imersão contínua, com aeração a cada 4 e 8 horas, apresentaram as maiores massas de matéria frescas de brotos (Tabela 1). O contato contínuo dos explantes com meio de cultura pode ter promovido maior absorção de água nesse sistema. Esta exposição continuada ao meio líquido pode causar distúrbios fisiológicos, como a hiperidricidade. O cultivo em sistemas temporários pode prevenir estas desordens pelo contato intermitente do meio de cultura com o material vegetal (Ziv, 1999).

Para massa de matéria seca de brotos, a melhor resposta foi verificada no sistema de imersão temporária a cada duas horas, com incremento de 100 a $250 \mathrm{mg}$, quando comparado aos sistemas de micropropagação convencional. O sistema de imersão temporária proporciona brotações mais pesadas para cana-de-açúcar, Amelanchier x grandiflora Rehd. 'Princess Diana' e abacaxizeiro (Lorenzo et al., 1998;

Tabela 1. Número de brotos, número de brotos maiores que $1 \mathrm{~cm}$, comprimento de brotos, matéria fresca e matéria seca de brotos de abacaxizeiro em diferentes métodos de cultivo in vitro ${ }^{(1)}$.

\begin{tabular}{|c|c|c|c|c|c|}
\hline Tratamento & $\begin{array}{l}\text { Número } \\
\text { de brotos }\end{array}$ & $\begin{array}{l}\text { Número de brotos } \\
>1 \mathrm{~cm}\end{array}$ & $\begin{array}{l}\text { Comprimento } \\
\text { de brotos }(\mathrm{cm})\end{array}$ & $\begin{array}{c}\text { Matéria fresca } \\
\text { de brotos }(\mathrm{g})\end{array}$ & $\begin{array}{l}\text { Matéria seca } \\
\text { de brotos }(\mathrm{g})\end{array}$ \\
\hline Meio líquido & $14,83 \mathrm{~b}$ & $10,00 \mathrm{~b}$ & $1,36 \mathrm{~d}$ & $4,31 \mathrm{~b}$ & $0,249 \mathrm{c}$ \\
\hline Ágar $\left(5 \mathrm{~g} \mathrm{~L}^{-1}\right)$ & $13,83 b$ & $3,49 \mathrm{c}$ & $1,10 \mathrm{~d}$ & $1,51 \mathrm{c}$ & $0,140 \mathrm{~d}$ \\
\hline Ágar $\left(6 \mathrm{~g} \mathrm{~L}^{-1}\right)$ & $5,91 \mathrm{~d}$ & $1,50 \mathrm{c}$ & $1,15 \mathrm{~d}$ & $1,20 \mathrm{c}$ & $0,100 \mathrm{e}$ \\
\hline Imersão contínua ( 2 horas) & $16,79 \mathrm{a}$ & $11,22 b$ & $1,83 \mathrm{c}$ & $4,73 b$ & $0,255 \mathrm{c}$ \\
\hline Imersão contínua (4 horas) & $11,33 \mathrm{c}$ & $11,33 \mathrm{~b}$ & $2,17 b$ & $6,42 \mathrm{a}$ & $0,255 \mathrm{c}$ \\
\hline Imersão contínua ( 8 horas) & $12,13 \mathrm{c}$ & $11,70 \mathrm{~b}$ & $2,28 b$ & $5,81 \mathrm{a}$ & $0,240 \mathrm{c}$ \\
\hline Imersão temporária ( 2 horas) & $18,87 \mathrm{a}$ & $15,60 \mathrm{a}$ & $2,55 \mathrm{a}$ & $4,87 \mathrm{~b}$ & $0,354 \mathrm{a}$ \\
\hline Imersão temporária (4 horas) & $18,42 \mathrm{a}$ & $17,00 \mathrm{a}$ & $2,52 \mathrm{a}$ & $4,73 b$ & $0,315 b$ \\
\hline Imersão temporária ( 8 horas) & $17,55 \mathrm{a}$ & $13,30 \mathrm{~b}$ & $1,68 \mathrm{c}$ & $3,84 \mathrm{~b}$ & $0,240 \mathrm{c}$ \\
\hline
\end{tabular}

${ }^{(1)}$ Médias seguidas pela mesma letra não diferem entre si pelo teste de Scott \& Knott, a 5\% de probabilidade. 
Escalona et al., 1999). Os sistemas de imersão, provavelmente, são mais apropriados ao crescimento de explantes em cultivo líquido em biorreatores (Paek et al., 2001; Etienne \& Bertholy, 2002).

A frequiência de aerações e imersões temporárias afetou diretamente o crescimento do cultivo em biorreator. Os efeitos dessa freqüência pareceram ser mais limitantes na multiplicação in vitro de abacaxizeiro em biorreator de imersão contínua, com tendência de queda dos números de brotos com a redução da freqüência de aerações de 12 vezes por dia, para 6 e 3 vezes. A imersão contínua promoveu maior massa de matéria fresca de brotações, principalmente em menores freqüências da renovação do ar nos recipientes de cultivo. Os sistemas de imersão temporária acionados a cada 2 horas promoveram brotações com maior massa de matéria seca, $47 \%$ superiores aos demais cultivos em biorretor (Tabela 1).

Em sistemas de imersão temporária, o tempo de imersão e a sua freqüência são muito importantes, determinando a absorção de nutrientes e controlando a hiperidricidade das plântulas (Etienne \& Berthouly, 2002). Na cultura de helicônia, intervalos menores entre as imersões promoveram o desenvolvimento e a propagação dos explantes em biorreator de imersão temporária (Rodrigues et al., 2006). A variação do tempo de imersão e sua freqüência devem ser determinadas de acordo com as exigências de cada cultivo.

A produção de mudas em biorreator de imersão temporária pode reduzir os custos de produção das plantas micropropagadas de abacaxizeiro, permitindo maior acesso aos fruticultores. A redução dos custos pode ser na redução do número de frascos, redução na manipulação do material, redução dos trabalhos de repicagem e aumento nas taxas de multiplicação (Chu, 1995). Escalona et al. (1999), em trabalho com micropropagação de abacaxizeiro em sistemas de imersão temporária, obtiveram $20 \%$ de redução nos custos de produção.

\section{Conclusão}

O sistema de imersão temporária é o método mais eficiente para a propagação em larga escala de abacaxizeiro.

\section{Referências}

ALVARD, D.; COTE, F.; TEISSON, C. Comparison of methods of liquid medium culture for banana micropropagation. Plant Cell, Tissue and Organ Culture, v.32, p.55-60, 1993.

CHU, I. Economic analysis of automated micropropagation. In: AITKEN-CHRISTIE, J.; KOZAI, T.; SMITH, M.A.L. (Ed.). Automation and environmental control in plant tissue culture. Dordrecht: Kluwer Academic Publishers, 1995. p.19-27.

DANQUITA, M.; BENEGAS, R. Brief review of tissue culture of pineapple. Pinepple News, n.3, p.7-9, 1997.

ESCALONA, M.; LORENZO, J.C.; GONZALEZ, B.L.; DANQUITA, M.; GONZALES, J.L.; DESJARDINS, Y.; BORROTO, C.G. Pineapple (Ananas comosus (L.) Merr.) micropropagation in temporary immersion systems. Plant Cell Reports, v.18, p.743-748, 1999.

ETIENNE, H.; BERTHOULY, M. Temporary immersion systems in plant micropropagation. Pant Cell, Tissue and Organ Culture, v.69, p.215-231, 2002.

FERREIRA, D.F. SISVAR 4.3: sistema de análises estatísticas. Lavras: UFLA, 1999. [programa de computador].

GEORGE, E.F. Plant propagation by tissue culture: in practice. Edington: Exegetics, 1996. 1361p.

KITTO, S.L. Commercial micropropagation. HortScience, v.32, p.1012-1014, 1997.

LEMOS, E.E.P. Micropropagação de clones de banana cv. terra em biorreator de imersão temporária. Revista Brasileira de Fruticultura, v.23, p.482-487, 2001.

LORENZO, J.C.; GONZALEZ, B.L.; ESCALONA, M.; TEISSON, C.; ESPINOSA, P.; BORROTO, C. Sugarcane shoot formation in an improved temporary immersion system. Plant Cell, Tissue and Organ Culture, v.54, p.197-200, 1998.

MURASHIGE, T.; SKOOG, F. A revised medium for rapid growth and bioassays with tobacco tissue culture. Physiologia Plantarum, v.15, p.473-497, 1962.

PAEK, K.Y.; HAHAN, E.J.; SON, S.H. Application of bioreactors for large-scale micropropagation systems of plants. In vitro Cellular Developmental Biology Plant, v.37, p.149-157, 2001. REINHARDT, D.H.R.C.; CUNHA, G.A.P. Métodos de propagação. In: CUNHA, G.A.P.; CABRAL, J.R.S.; SOUZA, L.F. da S. O abacaxizeiro: cultivo, agroindústria e economia. Brasília: Embrapa-SPI, 1999. p.105-138.

RODRIGUES, P.H.V.; TEIXEIRA, F.M.; LIMA, A.M.L.P.; AMBROSANO, G.M.B. Propagação de mudas de helicônia em biorreator de imersão temporária. Bragantia, v.65, p.29-35, 2006.

TEIXEIRA, J.B. Biorreatores. Biotecnologia Ciência \& Desenvolvimento, v.4, p.36-41, 2002.

ZIV, M. Organogenic plant regeneration in bioreactors. In: ALTMAN, A.; ZIV, M.; IZHAR, S. (Ed.). Plant biotechnology and in vitro biology in the $21^{\text {st }}$ century. Dordrecht: Kluwer Academic Publishers, 1999. p.673-676. 